\title{
Experiência interdisciplinar em Moçambique: programa um estudante uma família
}

\author{
Luiza Veloso Dutra, Sílvia Oliveira Lopes, Ana Maria Gonçalves Valente, Ramula Issa Juma
}

\begin{abstract}
Resumo
O Programa Um Estudante Uma Família (Um-EF) foi criado em 2007, como iniciativa da Universidade de Lúrio, instituição pública, localizada na Província de Nampula. Esta proposta emergiu da necessidade de criação de espaços de diálogo prático para abordagem de conteúdos construídos em sala de aula e que trouxesse maior aproximação entre os estudantes e a população que reside nas proximidades da faculdade. O programa objetiva a formação de profissionais da área da saúde que contribuam com a ciência para os esforços de luta contra a pobreza em Moçambique, por meio de planos curriculares que concorram para a criação do bem-estar individual e familiar, desenvolvendo habilidades nos agregados familiares e comunidades. O perfil curricular de cada curso lecionado na Faculdade de Ciências de Saúde, sendo eles nutrição, farmácia, optometria, medicina, enfermagem e medicina dentária, dão suporte ao Programa Um-EF por meio da disciplina Saúde da Comunidade, que conta com a participação dos alunos, durante todo o curso, sendo a mesma obrigatória. Além de buscar na construção coletiva um melhor entendimento dos temas propostos na área de saúde pública e epidemiologia. As aulas teóricas são ministradas por curso de forma individualizada e as aulas práticas realizadas em conjunto com os demais profissionais.

A preparação para o encontro com as famílias ocorre na semana anterior à visita onde os temas que serão levados até os domicílios são apresentados pelo curso responsável, elaborando lista de indicadores e fichas de inquérito às famílias (dados demográficos, sociais, econômicos, de saúde, problemas, expectativas, propostas). Em cada semestre letivo são formadas sete turmas da Saúde da Comunidade com média de 140 alunos cada, visitando cerca de 140 famílias. Após parcerias com os atores locais, dirigentes comunitários e chefes de família, são cadastradas as famílias participantes do programa, e é atribuído a ela um estudante de cada curso, totalizando um grupo de seis alunos por família, que a visitam quinzenalmente em conjunto. Contando com a participação dos professores durante a visita inicial e final do período. Durante as visitas são apresentados os objetivos, o Termo de Consentimento Informado e é realizado um inquérito sociodemográfico e de saúde, gerando assim um levantamento de problemas e prioridades, a serem estabelecidas ações de intervenção, podendo ter cunho de promoção, prevenção ou tratamento. Após as visitas são elaborados relatórios semestrais com análise e discussão dos dados coletados. Ao longo da formação os estudantes são incentivados a desenvolver trabalhos de investigação que possam contribuir para a melhoria do bem-estar das famílias e para o desenvolvimento das comunidades. A formação em Saúde da Comunidade constitui assim a metodologia interdisciplinar a todos os Cursos da Faculdade de Ciências de Saúde. A disciplina proporciona aos alunos a aplicação e humanização do diálogo junto às famílias, propondo estratégias mais eficazes e contextualizadas ao ambiente trabalhado, além de contribuir com a formação e mudança de perfis de saúde, já que segundo a FAO em seu relatório de 2015, 63\% dos moradores da zona rural não apresentam água potável e que 10 milhões de moçambicanos fazem suas necessidades "ao céu aberto". Esta realidade dificulta a disfunção de práticas de higiênicas básicas, porém é necessário trabalhar-se pontuando a importância dessas ações básicas no controle de doenças infecto parasitária que são uma realidade frequente no país.
\end{abstract}

Descritores: Saúde da família; Ensino; Interdisciplinaridade 